RESEARCH NOTE

\section{Photodegradation of the Molluscicidal Latex of "Crown-of-Thorns" (Euphorbia milii var hislopii)}

\section{EC Oliveira-Filho, FJR Paumgartten ${ }^{+}$}

\author{
Laboratório de Toxicologia Ambiental, Departamento \\ de Ciências Biológicas, Escola Nacional de Saúde \\ Pública, Fundação Oswaldo Cruz, Rua Leopoldo \\ Bulhões 1480, 21041-210 Rio de Janeiro, RJ, Brasil
}

Key words: plant molluscicides - schistosomiasis Euphorbiaceae - photostability - Euphorbia splendens - ecotoxicity

It has been demonstrated that the crude latex of "Crown-of-Thorns" (Coroa-de-Cristo) (Euphorbia milii var hislopii, syn. E. splendens var hislopii) is a rather potent plant molluscicide (MC Vasconcellos \& VT Schall 1986 Mem Inst Oswaldo Cruz 81: 475-476). Furthermore, "Crown-ofThorns" is easily cultivated in endemic areas, yields a large amount of latex throughout the year and, apparently, there is no marked seasonal or geographic variations in the molluscicidal potency of this natural product (DF Baptista et al. 1994 Southeast Asian J Trop Med Public Health 25: 419-424). The foregoing favourable characteristics make the crude latex of $E$. milii, lyophilized or in natura, an interesting alternative to the very expensive, and up-to-now imported, synthetic molluscicides used in the control of snails which are intermediate hosts of Schistosoma trematodes. Nonetheless, the large-scale use of any new pesticide, whether it be a synthetic compound or a natural product, requires a prior study of its risks to human health as well as to non-target organisms. Within this context, data on the fate of the product in the environment, and on the persistence of its biocidal effects are of toxicological significance. It was reported by V Schall et al. (1992 Rev Inst Med Trop São Paulo 34: 183191) that E. milii latex in natura stored at room temperature keeps its molluscicidal potency for at

Research supported by CNPq and PAPES-FIOCRUZ. This work is part of a MSc. Thesis of first author. ${ }^{+}$Corresponding author. Fax: +55-21-564.8985

Received 16 April 1997

Accepted 30 June 1997 least 124 days and that the lyophilized latex stored in the refrigerator is stable for two years. Despite these data suggesting that the lyophilized latex is a rather stable product, the same authors also noted that the molluscicidal activity of a $5 \mathrm{ppm}$ aqueous solution of latex was completely lost 30 days after preparation (Schall et al. loc. cit.). As far as we are aware, no data on the photostability of latex solutions are available in the scientific literature. Thus, the present study was undertaken to provide data on the effects of visible light on the persistence of molluscicidal activity of E. milii latex.

Latex of "Crown-of-Thorns" was obtained from plants cultivated in the district of Ilha do Governador, Rio de Janeiro, Brazil, in summer 1994-1995. A longitudinal incision was made in the plant stem and latex was collected in glass tubes which were further sealed and immediately transported to the laboratory facilities where it was lyophilized. Glass vials containing the lyophilized latex were then wrapped in aluminium foils and kept in the refrigerator $\left(0-4^{\circ} \mathrm{C}\right)$ until use. Two experiments were carried out. In the first experiment, Erlenmeyer flasks $\left(\right.$ PYREX $^{\circledR}, 1000 \mathrm{ml}$ ) containing a solution of lyophilized latex in distilled water (10 mg/l) were exposed to light (5000 lux), provided by a set of six cool white fluorescent lamps $\left(\right.$ OSRAM $\left.^{\circledR}, 20 \mathrm{~W}\right)$, for 24,48 and $96 \mathrm{hr}$. A solution of latex $(10 \mathrm{mg} / \mathrm{l}) \mathrm{kept}$ protected from light, in a dark environment, for $96 \mathrm{hr}$, as well as freshlyprepared latex solutions were used as controls. All latex solutions were diluted (to final concentrations as high as 0.5 and $1 \mathrm{mg} / \mathrm{l}$ ) immediately before testing their molluscicidal activity, which was evaluated in the snail assay employing Biomphalaria glabrata (from the breeding stock of the Department of Malacology, Oswaldo Cruz Institute). Groups of 10 adult snails (shell diameter 15-20 $\mathrm{mm})$ were placed in glass beakers $(2000 \mathrm{ml})$ containing the diluted solutions and snail lethality was evaluated $24 \mathrm{hr}$ after of exposure to E. milii latex. Bioassays were carried out under the usual conditions of temperature $\left(24 \pm 1^{\circ} \mathrm{C}\right)$, humidity $(70 \%)$, illumination and day/night cycle (approximately $12 \mathrm{hr}$ dark) maintained at the laboratory. A second experiment was performed to investigate the stability of molluscicidal latex solutions stored in the dark at a warm room temperature. Solutions of lyophilized latex $(10 \mathrm{mg} / \mathrm{l})$ were kept protected from light at $30 \pm 0.5^{\circ} \mathrm{C}$ for $2,9,16$ and 23 days before testing. Freshly-prepared latex solutions were used as controls. Molluscicidal activity was tested as previously described for the first experiment.

As shown in Table I, molluscicidal activity was drastically reduced by previous exposure of $E$. 
milli latex solutions to light (5000 lux). The reduction in lethal effect was clearly related to duration of previous exposure to light at the two concentrations of latex tested $(0.5$ and $1 \mathrm{mg} / \mathrm{l})$. A slight decrease in latex-induced toxicity was already detected after $24 \mathrm{hr}$ of exposure to light, a more pronounced reduction in snail lethality was noted following 48 $\mathrm{hr}$, and no molluscicidal activity was observed after $96 \mathrm{hr}$ of illumination. On the other hand, no difference in activity was found when a latex solution kept in the dark for $96 \mathrm{hr}$ was compared to a freshly-prepared control solution. These results indicate that molluscicidal activity is rapidly lost when aqueous solutions of latex are exposed to light and that the active principle(s) is (are) photodegradable. The spectral emission of the cool white fluorescent lamps used was determined and is similar to most of the commercially available $20-\mathrm{W}$ fluorescent lamps. These lamps show a maximum spectral irradiance in the range of wavelengths between $\lambda=$ $400 \mathrm{~nm}$ and $\lambda=700 \mathrm{~nm}$ (visible light), with lower levels of irradiance for wavelengths shorter than 400 nm (e.g. UV-B) (D Sliney \& M Wolbarsht 1980

\section{TABLE I}

Effect of exposure to light on the molluscicidal activity of aqueous solutions of Euphorbia milii lyophilized latex $(10 \mathrm{mg} / \mathrm{l})$. Lethality to Biomphalaria glabrata was evaluated by exposing snails to diluted solutions of latex $(0.5$ and $1 \mathrm{mg} / \mathrm{l})$ for $24 \mathrm{hr}$

\begin{tabular}{|c|c|c|c|}
\hline \multirow{2}{*}{$\begin{array}{l}\text { Duration of } \\
\text { exposure to } \\
\text { light ( } 5000 \text { lux })\end{array}$} & \multirow{2}{*}{$\begin{array}{c}\text { Latex } \\
\text { concentration } \\
(\mathrm{mg} / \mathrm{l})\end{array}$} & \multicolumn{2}{|c|}{$\begin{array}{l}\text { Mortality of } \\
\text { B. } \text { glabrata }^{a}\end{array}$} \\
\hline & & Dead / Exposed & $(\%)$ \\
\hline \multirow{2}{*}{$0 \mathrm{hr}^{b}$} & 0.5 & $9 / 10$ & 90 \\
\hline & 1 & $10 / 10$ & 100 \\
\hline \multirow{2}{*}{$24 \mathrm{hr}$} & 0.5 & $7 / 10$ & $70^{\bullet}$ \\
\hline & 1 & $9 / 10$ & 90 \\
\hline \multirow{2}{*}{$48 \mathrm{hr}$} & 0.5 & $4 / 10$ & $40 *, \bullet$ \\
\hline & 1 & $8 / 10$ & 80 \\
\hline \multirow{2}{*}{$96 \mathrm{hr}$} & 0.5 & $0 / 10$ & $0 *, \bullet$ \\
\hline & 1 & $0 / 10$ & $0^{*}, \bullet$ \\
\hline \multirow{3}{*}{$\begin{array}{l}\text { Control solution } \\
\text { in the dark for } 9\end{array}$} & ept & & \\
\hline & 0.5 & $9 / 10$ & 90 \\
\hline & 1 & $10 / 10$ & 100 \\
\hline
\end{tabular}

$a$ : statistical analysis was made by the chi-square test. Superscripts indicate mortality indices (\%) significantly different $(P<0.05)$ from those found for freshly-prepared solutions $(0 \mathrm{hr})$ containing either $0.5 \mathrm{mg} / \mathrm{l}(*)$ or $1 \mathrm{mg} / \mathrm{l}$ $(\bullet)$ of lyophilized latex; $b$ : freshly-prepared latex solutions.
Safety with Lasers and other Optical Sources. A Comprehensive Handbook. Plenum Press, New York, $1035 \mathrm{pp}$.). Since latex solutions were exposed to light through the glass envelope of the Erlenmeyer flasks, ultra-violet radiation should have been attenuated or eliminated. Therefore, in the present experimental conditions, UV light seemed to have played only a minor role, if any, in the photodecomposition of the molluscicidal ingredients of E. milii latex.

Data on the persistence of molluscicidal activity of aqueous solutions of E. milii latex stored in a dark and warm environment are presented in Table II. No decrease in molluscicidal activity was detected until the 9th day of storage, but a reduction of latex-induced snail lethality was observed following 16 days. On the other hand, on the 23rd day of storage the molluscicidal activity of latex solutions was markedly reduced. Since aqueous solutions of latex were kept in the dark, results of this second experiment suggest that degradation of the active principle(s) occurs in the absence of light as well.

\section{TABLE II}

Persistence of molluscicidal activity of aqueous solutions of Euphorbia milii latex $(10 \mathrm{mg} / \mathrm{l})$ stored in the dark at $30 \pm 0.5^{\circ} \mathrm{C}$. Lethality to Biomphalaria glabrata was evaluated by exposing snails to diluted solutions of latex $(0.5$ and $1 \mathrm{mg} / \mathrm{l})$ for $24 \mathrm{hr}$

\begin{tabular}{lccr}
\hline $\begin{array}{l}\text { Storage time } \\
\text { in a dark } \\
\text { environment }\end{array}$ & $\begin{array}{c}\text { Latex } \\
\text { concentration } \\
(\mathrm{mg} / \mathrm{l})\end{array}$ & $\begin{array}{c}\text { Mortality of } \\
\text { B. glabrata }\end{array}$ \\
\hline \multirow{2}{*}{ days $^{b}$} & 0.5 & $28 / 30$ & 93.3 \\
& 1 & $29 / 30$ & 96.7 \\
2 days & 0.5 & $10 / 10$ & 100 \\
& 1 & $10 / 10$ & 100 \\
9 days & 0.5 & $10 / 10$ & 100 \\
& 1 & $10 / 10$ & 100 \\
16 days & 0.5 & $7 / 10$ & $70^{*, \bullet}$ \\
& 1 & $9 / 10$ & 90 \\
23 days & 0.5 & $3 / 10$ & $30^{*, \bullet}$ \\
& 1 & $5 / 10$ & $50^{*, \bullet}$ \\
\hline
\end{tabular}

$a$ : statistical analysis was made by the chi-square test. Superscripts indicate mortality indices (\%) significantly different $(P<0.05)$ from those found for freshly-prepared solutions $(0 \mathrm{hr})$ containing either $0.5 \mathrm{mg} / \mathrm{l}(*)$ or $1 \mathrm{mg} / \mathrm{l}$ $(\bullet)$ of lyophilized latex; $b$ : freshly-prepared latex solutions. 
In conclusion, data from both experiments clearly indicate that aqueous solutions of E. milli latex are not stable at room temperature, and that the rate of degradation of their molluscicidal ingredients is enhanced when latex solutions are exposed to light. Owing to the marked susceptibility to photodegradation, biocidal activity of $E$. milii latex is expected to be of very short duration under field conditions, particularly if this plant molluscicide is applied in areas exposed to full sunlight.

Acknowledgments: to Dr Lygia dos Reis Corrêa, Oswaldo Cruz Institute, for kindly providing the snails used in this study. To the staff of the Section of Environment and Biotechnology of CENPES-Petrobrás for laboratory facilities. 
